
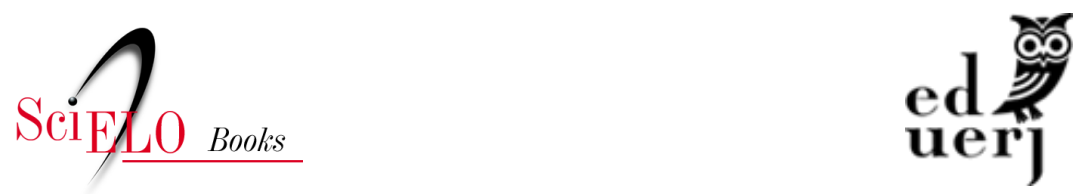

\title{
6. Prólogo à entrevista com Estela dos Santos Abreu
}

\author{
Vanessa Massoni da Rocha
}

\section{SciELO Books / SciELO Livros / SciELO Libros}

ROCHA, V. M. Prólogo à entrevista com Estela dos Santos Abreu. In: Tradução em (ent)revista: Simone Schwarz-Bart e as tradutoras brasileiras [online]. Rio de Janeiro: EDUERJ, 2021, pp. 51-52. Letras UERJ collection. ISBN: 978-65991111-5-0. https://doi.org/10.7476/9786599111150.0006.

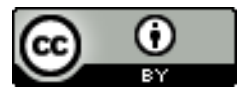

All the contents of this work, except where otherwise noted, is licensed under a Creative Commons Attribution 4.0 International license.

Todo o conteúdo deste trabalho, exceto quando houver ressalva, é publicado sob a licença Creative Commons Atribição 4.0.

Todo el contenido de esta obra, excepto donde se indique lo contrario, está bajo licencia de la licencia Creative Commons Reconocimento 4.0. 


\section{Prólogo à entrevista com Estela dos Santos Abreu}

Restaurante Lamas, 28 de agosto de 2016, sexta-feira.

Estamos na parte de trás do restaurante tentando nos esquivar dos barulhos das famílias almoçando e dos torcedores do Flamengo assistindo à partida contra o Figueirense pela Copa Sul-Americana. Estela inicia a entrevista mostrando uma fotografia dela com Simone Schwarz-Bart no café parisiense Les Deux Magots em 2011. Dispõe a imagem sobre a mesa e fala de como conheceu a escritora e dos reencontros entre as duas.

A entrevista ganha novos contornos: suspendem-se, por ora, as perguntas e entra em cena o elogio à amizade nascida nas tramas da tradução. Emergem os testemunhos mais espontâneos e as mais variadas lembranças: o tom de voz, a postura, a personalidade, a exuberância, as cores, enfim, todo o universo que, segundo Estela, singulariza a escritora antilhana. Era a primeira vez que Estela falava de Simone, a primeira vez que mostrava a foto, e essa cumplicidade entre as duas 
me convencia das travessias e dos encontros que se tecem nas malhas da tradução. Encontros que extrapolam o espaço textual, aludindo à afetividade que alimenta sua prática. Ao mostrar o retrato e falar de maneira entusiasmada da relação com a escritora, Estela aponta para as singularidades de cada processo de tradução. Eu, que esperava encontrar uma tradutora disposta a falar de técnicas desenvolvidas ao longo de mais de oitenta e cinco projetos de tradução, encontro alguém transbordando encantamento e exaltando as duas ou três vezes em que esteve com a amiga. Já não escuto as famílias barulhentas, as crianças que correm por entre as mesas, os garçons que são chamados com assobios e o jogo do Flamengo na televisão. O Flamengo, é preciso que se diga, perdeu de 4 X 2 para o Figueirense, para descontentamento dos rubro-negros. E eu penetrei "surdamente no mundo das palavras", das fotos, das histórias e das lembranças compartilhadas. 